Anna Rygorowicz-Kuźma

Bialystok

\title{
Terminologia prawosławna w rosyjsko-polskich słownikach specjalistycznych
}

Słowa kluczowe: terminologia religijna, prawosławie, słowniki dwujęzyczne, słowniki specjalistyczne

Religia to jedna ze sfer życia społecznego, która zarówno w Polsce, jak i w Rosji jest wyraźnie zauważalna. Choć historia obydwu państw znacznie się różni, losy chrześcijaństwa zachodniego i wschodniego na tych ziemiach są częściowo podobne. Wspomnieć tu należy chociażby wiek ubiegły, kiedy przez długie dziesiątki lat komunizmu religia i wiara były prześladowane i marginalizowane, choć represje religijne były znacznie bardziej dotkliwe w krajach byłego Związku Radzieckiego, w tym w Rosji. Dopiero koniec XX stulecia wraz ze zmianami społeczno-politycznymi przyniósł odrodzenie religijne i ogólny wzrost zainteresowania sferą sacrum. Dziś terminologia religijna spotykana jest nie tylko $\mathrm{w}$ tekstach o charakterze religijnym, ale też pracach o tematyce świeckiej, w radiu i telewizji, w publicystyce i współczesnej literaturze pięknej. Czytelnik polski, stykając się z tekstami w języku rosyjskim dotyczącymi prawosławia, niewątpliwie stanie przed problemem ich zrozumienia. Pomocy będzie szukał w ogólnych słownikach rosyjsko-polskich, ale te utrwalają leksykę religijną w sposób wybiórczy, włączając tylko jednostki podstawowe, najczęściej spotykane. Większość słownictwa religijnego pozostanie więc niezrozumiała. Niezwykle pomocne okażą się w tym przypadku sprofilowane pod kątem obszaru religijnego słowniki specjalistyczne, które, niestety, nie są liczne. Jak zauważa Roman Lewicki „leksyka religijna pozostaje nadal jednym z najsłabiej opisanych przez leksykografię dwujęzyczną w Polsce fragmentów słownictwa" [LCh, Wstęp, 7]. 
Na polskim rynku wydawniczym do tej pory ukazało się zaledwie parę takich prac, zapoczattkowanych przez opublikowany w 1994 r. Podręczny słownik rosyjsko-polski $i$ polsko-rosyjski terminów chrześcijańskich autorstwa M. Sztolberg-Bybluk ${ }^{1}$.

Wśród słowników specjalistycznych poświęconych leksyce religijnej na uwagę zasługują prace R. Lewickiego Chrześcijaństwo. Stownik rosyjsko-polski (dalej LCh) i A. Markunasa, T. Uczitiel Leksykon chrześcijaństwa rosyjsko-polski i polsko-rosyjski (dalej MUL). Są to na dzień dzisiejszy najbardziej obszerne dwujęzyczne źródła skupiające interesującą nas terminologię2 ${ }^{2}$, choć wspomnieć należy, że włączają one zarówno terminy chrześcijaństwa zachodniego, jak i wschodniego.

Każdy ze słowników jest propozycją odrębną, różniącą się przyjętą metodą opisu, strukturą i częściowo zakresem leksyki. Leksykon Antoniego Markunasa i Tamary Uczitiel to typowy słownik dwujęzyczny wzbogacony zwięzłymi objaśnieniami haseł w języku rosyjskim³ ${ }^{3}$ Autorzy, mając na uwadze fakt, iż podanie samych ekwiwalentów w przypadku leksyki konfesyjnej nie jest wystarczające ze względu na „brak merytorycznego przygotowania użytkownika do obcowania ze słownictwem religijnym" [MUL, Wprowadzenie, 5], poprzez definicje chcą przybliżyć mu treść semantyczną pojęć sakralnych. Leksykon adresowany jest do szerokiego grona odbiorców z przeznaczeniem poznawczym i dydaktycznym.

Publikacja Romana Lewickiego to słownik, jak podkreśla autor, objaśniająco-przekładowy. Jest on przeznaczony dla osób „w pewnym stopniu znających już język rosyjski i zainteresowanych prawosławiem i kulturą religijną Rosjan, w szczególności dla tłumaczy oraz dla osób uczących się języka rosyjskiego" [LCh, Wstęp, 9]. Słownik ten charakteryzuje układ gniazdowy, hasło zawiera nie tylko wyrażenie hasłowe, ale też jego derywaty oraz kolokacje z danym wyrazem. Artykuł hasłowy uzupełniony jest dodatkowo wybranym materiałem egzemplifikacyjnym, ukazującym zarówno przykłady elementarnych połączeń, jak też cytaty z tekstów rosyjskich wraz z ich tłumaczeniem na język polski.

1 Obok słownika M. Sztolberg-Bybluk [1994] i omawianych w artykule prac R. Lewickiego (LCh) i A. Markunasa, T. Uczitiel (MUL) należy tu wymienić leksykon H. Fiediukiny [2014]; niewielki słowniczek poświęcony prawosławiu dołączony też jest do materiałów dydaktycznych do nauki języka rosyjskiego autorstwa G. Skowrońskiej-Płaczynty [1995, 1998].

2 Nie uwzględniam tu najnowszej pracy Heleny Fiediukiny [2014], której, ze względu na jej specyfikę, chcę poświęcić odrębną uwagę.

$3 \mathrm{~W}$ związku z podjętym tematem pod uwagę będzie brana tu tylko pierwsza część słownika, tzn. Stownik rosyjsko-polski. 
Ekscerpcja terminologii prawosławia z omawianych źródeł nie sprawiła większych trudności, gdyż w objaśnieniach haseł dotyczących realiów charakterystycznych tylko dla konkretnego obrządku często stosowane były odpowiednie informacje, zob. np.: apxuеnucкоn - старший епископ, один из высших чинов церковной иерархии; в православии присваивается как почетный титул, в католицизме равен званию митрополита (LCh, 51), Проскомидия - первая часть православной Литургии (...) (MUL, 185) itp.

Oba źródła rejestrują interesującą nas leksykę w szerokim zakresie. Włączają leksemy charakterystyczne dla obrzędowości i duchowości prawosławia, dotyczące zarówno jej materialnej strony, na przykład nazwy budynków cerkiewnych i ich części, określenia osób duchownych i laikatu, określenia przedmiotów, naczyń i szat liturgicznych (zob. np. hasła: $\kappa e-$ лья, подворье, собор, архимандрит, иерей, исповедник, причастнича, аналой, епитрахиль, просфора, служебник i in.), jak i niematerialnej, duchowej, wskazującej na pojęcia wiary, sakramenty, nabożeństwa i ich części oraz cykl świąteczny (zob. np. hasła: триединство, покаяние, исповедь, крещение, литургия, лития, успенский пост, Богоявление, Пас$x a \mathrm{i}$ in.). Obok leksyki podstawowej fiksują wąskospecjalistyczne terminy teologiczne, których znajomość nie jest powszechna nawet w środowisku prawosławnych, zob. nр.: анафора, епиклезис, икономия, парусия, теологумен itp. W słownikach znalazła odzwierciedlenie zarówno terminologia oficjalna (nр.: священнослужитель, Преображение Господне, аналогий itp.), jak też leksemy funkcjonujące w użyciu ustnym, potocznym (zob. np.: батюшка, Спас, Филипповки, налой i in.). Oba źródła rejestrują też obszernie różnorodne nazwy własne, zob. nр.: Александро-Невская лавра, Зографское евангелие, Василий Великий, Христос Панmократор, Tроеручица i in. Pod względem ilości zawartych haseł (czy podhaseł) leksykony, choć objętościowo podobne, raczej się uzupełniają niż powielają.

Pomimo wspólnych korzeni tradycje chrześcijańskie Rosji i Polski znacznie się różnią, dlatego też wiele trudności napotkamy w sferze przekładu rosyjskiej leksyki religijnej na język polski. W tym miejscu pominięto terminy ogólnochrześcijańskie, wspólne obydwu Kościołom (np. апостол, евхаристия, утреня, епискоn, молитва i in.), których translacja nie stanowi problemu. Analizie zostaną poddane hasła związane ze specyfiką prawosławia, jego liturgiką, obrzędowością i duchowością, nieobecne w katolickiej kulturze polskiej. Autorzy omawianych słowników stosowali różne procedury translatorskie, starając się dobrać jak najbardziej odpowiednie ekwiwalenty. Ich zadanie nie było łatwe, nie tylko ze względu na obcość nie- 
których realiów i pojęć prawosławia w kulturze polskiej, ale też różnice w realiach na pozór zbieżnych czy możliwe konotacje leksemów. Po części pomocą mogły służyć tu terminy, funkcjonujące już w subjęzyku społeczności prawosławnej zamieszkującej obszary Polski. Należy jednak podkreślić, że terminologia prawosławna w języku polskim to obszar stosunkowo nowy, który dopiero się kształtuje i formuje. Polski Autokefaliczny Kościół Prawosławny posługuje się w liturgii tradycyjnym dla Słowian językiem cerkiewnosłowiańskim, w życiu codziennym ważną rolę odgrywają lokalnie języki narodowe wiernych, np. białoruski, rosyjski, ukraiński, łemkowski. W ostatnich dwóch dziesięcioleciach dynamicznie wzrasta też rola języka polskiego w Cerkwi. W tym języku nauczana jest religia w szkołach, prowadzone są zajęcia dla alumnów i studentów studiów wyższych, coraz częściej język polski spotykany jest w kazaniach, a nawet w liturgii ${ }^{4}$. Z każdym rokiem wzrasta też liczba polskojęzycznych publikacji i czasopism poświęconych prawosławiu. Tym bardziej zauważalna jest potrzeba pewnej systematyzacji, standaryzacji i unifikacji terminów prawosławia, co jest zadaniem przede wszystkim sprofilowanych pod tym kątem źródeł leksykograficznych.

W analizowanych słownikach znaczną grupę translatów stanowią kalki fonetyczne terminów rosyjskich, które z kolei są najczęściej cerkiewnosłowianizmami, zob. np.: аналой $\operatorname{anałoj~(LCh,~43-44),~акафистник~•~akafist-~}$ nik (LCh, 41), архиереŭ • archijerej (MUL, 23), батюшка • batiuszka (pot.) (LCh, 54), владыка •władyka (pot.) (LCh, 85), воздух• wozduch (LCh, 87), дароносича $•$ daronosica (LCh, 100), епитимия • еріtimia (LCh, 113), звездища • zwiezdica (MUL, 79), панихидник • panichidnik (LCh, 141), плащанища • plaszczanica (LCh, 204), полунощнища • potunoszcznica (MUL, 168), регент • regent (LCh, 233), славословие - stawostowie (LCh, 253) i inne. Jest to sposób jak najbardziej naturalny, zważając na fakt, że zarówno Cerkiew rosyjska, jak i polska posługuje się w liturgii językiem cerkiewnosłowiańskim.

Kolejny dość częsty sposób translacji obserwowany w słownikach to kalki słowotwórcze, zob. np.: apxистратиг • arcystrateg (MUL, 24), благоверный - prawowierny (MUL, 28), звездица • gwieździca (LCh, 119), Евангелистаpuй $•$ Ewangelistarz (LCh, 110), Ewangelistariusz (MUL, 70), миропомазание - chryzmopomazanie (MUL, 129), мясопycm • mięsopust (LCh, 197), набедренник• nabiedrzec (MUL, 140), повечерие • powieczerze (LCh, 204),

4 Choć oficjalnie językiem liturgicznym Polskiego Autokefalicznego Kościoła Prawosławnego jest język cerkiewnosłowiański, w wielu parafiach (przede wszystkim w miastach) nabożeństwa celebrowane są również w języku polskim. 
предпразднество • przedświęcie (LCh, 215), сороковинь • czterdzieściny (MUL, 215), Hecmoncaлмие • Sześciopsalm (MUL, 262) i in.

Aktywna, choć nietypowa dla starszych źródeł leksykograficznych strategia translatorska to zastosowanie $\mathrm{w}$ funkcji translatu terminu greckiego, zob. np.: apтофор • artoforion (MUL, 23), Богогласник - Tеofonikon (MUL, 32), величание - megalinarion (MUL, 42), дароносича • artoforion, artofor (MUL, 60), жезлоносеи • paterysfor (MUL, 76), кондак - kondakion (LCh, 149), Молитвослов полный • Horologion (MUL, 134), подризник • spec. parafelonion (LCh, 235), nomup • poterion (MUL, 173), noяc $\bullet$ zonarion (spec.) (LCh, 216), nоручи $\bullet$ epimanikion (spec.) (LCh, 211), светилен - Fotagogikon (MUL, 198), трисвятое - trisagion, trisagium (MUL, 232), троичен • triadikon (LCh, 270) itp. Choć stosowanie greckich odpowiedników jest tendencją dosyć nową, dającą się zauważyć od lat 90-tych XX wieku, to wyraźnie się aktywizuje. Potwierdzeniem tego zjawiska może być chociażby porównanie rozwiązań translatorskich dla danych haseł zastosowanych w starszych źródłach, np. wydanym w $1994 \mathrm{r}$. słowniku M. Sztolberg-Bybluk (dalej PSCh), zob. np.: nодризник • podryźnik (PSCh, 61), spec. parafelonion (LCh, 235), прокимен • prokimen (PSCh, 68), prokimenon (LCh, 226), Tpuodb • Triod (PSCh, 84), Triodion (MUL, 232; LCh, 269) i in.

Omawiając sposoby translacji rosyjskiej terminologii prawosławia należy zwrócić uwagę na hasła, które w języku docelowym (w naszym przypadku polskim) otrzymują dwa bądź więcej ekwiwalentów. Teoretycznie leksyka specjalistyczna powinna być jednoznaczna i jednemu terminowi po stronie lewej słownika powinien odpowiadać jeden translat po stronie prawej. Dlaczego tak nie jest? Analiza artykułów hasłowych pozwala na wyodrębnienie różnych przyczyn. Są to zjawiska dotyczące zarówno funkcjonowania terminologii prawosławia w języku polskim, jak i sposobów jej przekładu. Dość często translaty, choć różne, okazują się synonimami dokładnymi terminu rosyjskiego. Część z nich to polskie warianty fonetyczne tego samego terminu, będącego bezpośrednim zapożyczeniem greckim bądź cerkiewnosłowiańskim, por. np.: zwiezdica (cs.) / asteriskos (gr.) (MUL, 79), anałoj (cs.) / analogion (gr.) (LCh, 43-44) i in. Oprócz par: zapożyczenie cerkiewnosłowiańskie - zapożyczenie greckie często w roli równorzędnych ekwiwalentów występują obok siebie: jednostka leksykalna rodzima i zapożyczenie (najczęściej greckie), por. np.: прокимен - prokimenon, werset psalmu (LCh, 226), величание - megalinarion, hymn liturgiczny (MUL, 42), завеса • zastona, katapetasma (MUL, 78), жезл - pastorat, laska pasterska, rzad. pateryca (LCh, 113), жертвенник - stót ofiarny, żertwiennik (LCh, 114), nояc • pas, spec. zonarion (LCh, 216) itp. 
Zdarzają się też warianty (fonetyczne, graficzne, gramatyczne) spolszczeń cerkiewnosłowianizmów i grecyzmów, np.: zwiezdica / gwiezdica (MUL, 79), kibot / kiwot / kiot (LCh, 144), orar / orara (LCh, 192), irmologion / hirmologion (MUL, 89), dyptyk / deptych (MUL, 64) itp., świadczące o braku jednoznacznych ustaleń dotyczących zapisu takiej terminologii w języku polskim.

W każdym języku to samo zjawisko, denotat może być określony przez kilka wyrażeń synonimicznych, zarówno rodzimych, jak i zapożyczonych. Mogą one funkcjonować w oficjalnej nomenklaturze bądź użyciu ustnym, w wąskim gronie specjalistów bądź języku przeciętnego użytkownika języka. Takie zróżnicowanie obserwujemy i wśród polskich ekwiwalentów rosyjskiej leksyki prawosławia, por. nр.: священник - kapłan, prezbiter, ksiadz (MUL, 202), Богоявление - Epifania, Teofania, Objawienie Pańskie (MUL, 38), звездииа •gwiazda, gwieździca, spec. asterysk, spec. asteriskos (LCh, 119), владька • pot. Władyka, pot. wzn. przewielebny ojciec; biskup; arcybiskup (LCh, 85), камилавка - kamiławka, spec. rzad. skiadion (LCh, 139), дароносича $\bullet$ daronosica, spec. artoforion (LCh, 100) itp. W przypadku wystąpienia takich wariantów synonimicznych jednostka rodzima staje się formą najbardziej powszechną, dostępną dla przeciętnego użytkownika języka, zapożyczenie cerkiewnosłowiańskie funkcjonuje przede wszystkim w środowisku wyznawców prawosławia, dość często w użyciu ustnym, zapożyczenia greckie natomiast przyjmują najczęściej charakter terminów specjalistycznych, używanych w wąskim kręgu duchowieństwa i specjalistów w dziedzinie prawosławia.

Omawiając terminologię religijną należy zwrócić uwage na hasła, nazywające realia prawosławia, dla których istnieją w katolicyzmie funkcjonalnie analogiczne zjawiska. Roman Lewicki (LCh) wyraźnie różnicuje terminologicznie oba obszary, a analogi funkcjonujące w katolicyzmie podaje po odpowiednim znaku graficznym, zob. np.: nодрясник - podriasnik, || sutanna (LCh, 238), Фомина неделя - Niedziela Przewodnia, Biała Niedziela, || Niedziela Miłosierdzia Bożego (LCh, 275), Рождественский nост (= Филипповский пост, разг. Филипповки) - Post Filipowy, $\|$ adwent (LCh, 214) itp. Takie rozwiązanie jest jak najbardziej właściwe, gdyż wskazuje na realia prawosławne i katolickie, które, choć podobne, mogą być mylnie utożsamiane. Z drugiej strony ułatwia wybór translatu w zależności od charakteru tłumaczonego tekstu. Słownik A. Markunasa, T. Uczitiel jest pod tym względem uboższy, traktując takie ekwiwalenty równorzędnie, bez dodatkowego komentarza, zob. np.: жезл - pastorat, pateryca (MUL, 76), Обедня •Liturgia, msza, suma (MUL, 146), игуменья • przеorysza, ksieni, ihumenia (MUL, 80) i in. Nierzadko też w MUL w roli od- 
powiednika terminu prawosławnego występuje tylko leksem wskazujący na realia katolickie, zob. nр.: подрясник• odpowiednik sutanny, strój nieoficjalny (MUL, 167), навечерие Богоявления • wieczór Trzech Króli (MUL, 140), Рождественский пост • adwent (MUL, 194), служебник архиерейский - pontyfikat (MUL, 213) itp. Obecność takich analogów w roli słownikowych odpowiedników przekładowych jest jak najbardziej zasadna, ale niezbędny jest w takich przypadkach dodatkowy komentarz, wskazujący na kulturowy (wyznaniowy) obszar użycia.

Dokładna translacja terminologii dość obcej w polskiej kulturze religijnej jest w wielu przypadkach niemożliwa. Autorzy słowników w różny sposób i z różnymi rezultatami starają się przezwyciężyć ten problem. W słowniku A. Markunasa i T. Uczitiel dość często w roli ekwiwalentów pojawiają się krótkie opisy denotatu, zob. np.: апостольник • element ubioru mnicha i mniszki (MUL, 21), великомученик - męczennik, który cierpiat szczególnie surowe męki (MUL, 42), всенощная • nabożeństwo złożone z wieczerni, jutrzni i pierwszej godziny kanonicznеј (MUL, 52), Изобразительные • rоdzaj psalmów (MUL, 82), малосхимник • mnich, który złożył zwykłe śluby zakonne (MUL, 121), перезвон • sposób dzwonienia (MUL, 164), рясофор - strój mniszy braci próbantów (MUL, 196) i in. Taka swoista peryfraza, choć pozwala na zrozumienie terminu wyjściowego, najczęściej nie nadaje się do zastosowania w tłumaczonym tekście. Pod tym względem bardziej pomocny jest słownik Romana Lewickiego (LCh), w którym w przypadku nieprzekładalności terminu wprowadzane są ekwiwalenty niepełne, ze wskazaniem na rodzaj rozwiązań translatorskich, zob. np.: богородичен $\cdot$ hymn Maryjny, hymn ku czci Matki Bożej, (konkretnie) troparion ku czci Matki Bożej (LCh, 72), повечерие - powieczerze, (opisowo) nabożeństwo po wieczerni, $\approx$ (ogólnie) nabożeństwo wieczorne (LCh, 204), мясоед• $\varnothing$, (opisowo) okres wolny od postu, (ze zmianą konstrukcji) kiedy nie ma postu, $\approx$ (konkretnie) zapusty (LCh, 178), обuxод•, , (opisowo) księga śpiewu cerkiewnego, \| kancjonat (LCh, 188) itp.

Jak trudne, specyficzne i wymagające pewnej wiedzy i obycia jest tłumaczenie leksyki prawosławia mogą świadczyć chociażby przykładowe jednostki leksykalne, wynotowane z analizowanych słowników. Uwagę zwraca na przykład translat Wielki Tydzień odniesiony nie tylko do rosyjskich połączeń tyрu страстная неделя, страстная седмича, ale też wyrażeń пасхальная неделя (LCh, 200), Светлая неделя (MUL, 199), седмича пасхальная (MUL, 205). Zarówno w tradycji zachodniego, jak i wschodniego chrześcijaństwa Wielki Tydzień to okres ostatniego tygodnia przed Zmartwychwstaniem Pańskim. Trudno wytłumaczyć, dlaczego różne znaczeniowo połączenia otrzymały identyczny ekwiwalent Wielki Tydzień (!). 
Określenia пасхальная неделя, светлая неделя dotyczą tygodnia paschalnego, tygodnia, który zaczyna się Zmartwychwstaniem Pańskim (rosyjska oficjalna nazwa: Светлое Христово Воскресение). Z kolei hasła: Цветоносная неделя • Wielki Tydzień (MUL, 253), Вербная неделя - tydzień przed Niedziela Palmowa (MUL, 43), неделя о блудном сыне - tydzień przed zapustami (MUL, 142) itp. wskazują na problem związany z tłumaczeniem na język polski leksemu неделя, zwłaszcza w nazwach świąt. W języku rosyjskim wyraz ten oznacza oczywiście okres tygodniowy, w języku cerkiewnosłowiańskim natomiast, podstawowym dla słowiańskich nazw świąt prawosławnych, неделя to inaczej воскресенье 'niedziela', tydzień określany jest zaś przy pomocy cerkiewnosłowiańskiego leksemu седмица. Dlatego też ekwiwalentem określeń uветоносная неделя і вербная неделя jest Niedziela Palmowa, неделя о блудном сыне to zaś Niedziela o synu marnotrawnym. Co ciekawe, autorzy haseł słownikowych posiadają, a nawet przytaczają wiedzę o różnicy w rozumieniu wyrazu неделs, mimo to podają błędny odpowiednik, zob. np.: Крестопоклонная неделя - третье воскресенье (церк.-слав. неделя) великого поста, посвященное поклонению кресту; (...) • Туdzień Adoracji Krzyża Św., połowa Wielkiego Postu (LCh, 155) i in. Oczywiście są też przykłady prawidłowego rozumienia niedzieli, nр.: Неделя о блудном сыне - Niedziela o Synu Marnotrawnym (LCh, 181), Неделя о Страшном суде • Niedziela o Sadzie Ostatecznym (LCh, 181) i in.

Jeszcze jedna uwaga, jaką należy poświęcić wyrazowi pop. W obu analizowanych słownikach odnajdujemy sprzeczne informacje na temat tego leksemu. W słowniku A. Markunasa, T. Uczitiel w części rosyjsko-polskiej zarejestrowane jest hasło: non - название человека поставленного, посвящённого, помазанного в духовный чин или сан пастыря душ • pop, ksiadz prawostawny (MUL, 170), sugerujące neutralne, a nawet wzniosłe zabarwienie wyrazu, natomiast w części polsko-rosyjskiej hasło: $p o p$ - potoczna, lekceważąca nazwa duchownego w Kościele prawosławnym; batiuszka • non (MUL, 333), wyraźnie ma nacechowanie pejoratywne. Negatywne zabarwienie ma również wyraz non w słowniku R. Lewickiego, por.: non - устар. разг. с оттенком пренебрежит. православный священник - рор (LCh, 211). Ale translat рор zanotowany $\mathrm{w}$ artykule hasłowym: батюшка - разг. православный священник - рор, pot. batiuszka, (w Polsce) ksiadz, pot. 〈ksiadz〉 dobrodziej (LCh, 54), wydaje się już formą neutralną, równoważną leksemowi ksiadz. Choć leksem pop wciąż rejestrowany jest w wielu źródłach leksykograficznych jako neutralne określenie duchownego prawosławnego, jest to w środowisku prawosławnych nazwa pejoratywna, synonimiczna określeniu klecha. Uży- 
cie określenia pop w stosunku do osoby duchownej jest dużym nietaktem, choć najczęściej niezamierzonym. Zagadnienie konotacji wyrazu pop zostało poruszone w monografii Edwarda Klicha [1927, 112] i paru artykułach naukowych ${ }^{5}$, na ograniczenia w użyciu tej nazwy wskazują niektóre słowniki ${ }^{6}$, jest więc nadzieja, że w kolejnych publikacjach leksykograficznych wiedza o współczesnym zabarwieniu leksemu pop zostanie uwzględniona, tym bardziej, gdy dotyczy to prac poświęconych nazewnictwu religijnemu.

Podsumowując powyższe rozważania należy stwierdzić, że słowniki przedstawiają leksykę prawosławia w dość szerokim zakresie, pozwalającym na zrozumienie nie tylko tekstów nawiązujących do prawosławia, ale i po części tekstów specjalistycznych, teologicznych. Użytkownik słownika dokonujący tłumaczenia spotka się jednak z wieloma problemami. Nierzadko stanie przed koniecznością losowego wyboru ekwiwalentu, zwłaszcza w przypadkach, gdy te wymienione są jako równoważne, bez dodatkowej informacji różnicującej. W szeregu haseł zamiast ekwiwalentu odnajdzie jego zwięzłą definicję, niezdatną do podstawienia w tłumaczonym tekście. Ale problem doboru właściwego ekwiwalentu wynika nie tylko z różnych rozwiązań translatorskich zastosowanych w słownikach, ale też z wariantywności leksyki prawosławia w języku polskim. Leksyka ta nie jest uporządkowana i jednoznacznie ustalona. Prawosławie polskie od wieków zachowuje liturgię cerkiewnosłowiańską, dlatego wiele terminów to zapożyczenia cerkiewnosłowiańskie, często notowane w różnych fonetycznych i graficznych wariantach. Stopniowo zaznacza się też tendencja do wprowadzania grecyzmów, które stają się dubletami cerkiewnosłowianizmów bądź nawet je wypierają. Poza tym terminologia prawosławna wykorzystuje również zasoby języka polskiego, a czasami adaptuje też wyrażenia pochodzenia łacińskiego. Pamiętając, iż duchowość prawosławia jest dość obca kulturze polskiej, niezwykle łatwo jest o pomyłkę natury merytorycznej czy stylistycznej, niezgrabność bądź niestosowność użycia danej jednostki leksykalnej, co zauważamy niestety nawet w słownikach poświęconych leksyce religijnej. Słownictwo tego obszaru podczas opracowania leksykograficznego wymaga więc nie tylko pewnego zasobu wiedzy, ale też dużej skrupulatności, intuicji językowej i kulturowego wyczucia.

5 Zob. np.: M. Karpluk [1989, 140], E. Badyda [2010], A. Rygorowicz-Kuźma [2011, 408-409].

6 Zob. np.: pop - pot. 'duchowny w Kościele prawosławnym i grekokatolickim'. Uwaga: określenie używane przede wszystkim przez osoby niebędące wyznania prawosławnego (SPP, 370); pop - potoczne, często lekceważące określenie księdza [...] (NLP, 1365) i in. 


\title{
Wykaz skrótów
}

LCh - Lewicki R., 2002, Chrześcijaństwo. Słownik rosyjsko-polski, Warszawa.

MUL - Markunas A., Uczitiel T., 1999, Leksykon chrześcijaństwa rosyjsko-polski i polsko-rosyjski, Poznań.

NLP - Nowy leksykon PWN, 1998, red. A. Dyczkowski, Warszawa.

PSCh - Sztolberg-Bybluk M., 1994, Podreczny słownik rosyjsko-polski i polsko-rosyjski terminów chrześcijańskich, Torun.

SPP - Podlawska D., Świątek-Brzezińska, 2011, Stownik poprawnej polszczyzny, Warszawa-Bielsko-Biała.

\section{Literatura}

Badyda E., 2010, Pop czy ksiadz? O problemie wspótczesnego nacechowania tradycyjnej nazwy duchownego prawosławnego, "Poradnik Językowy”, nr 9/2010, s. $57-72$.

Fediukina H., 2014, Leksykon terminologii prawosławnej rosyjsko-polski, Warszawa.

Karpluk M., 1989, Stownictwo cerkiewne w polszczyźnie XVI w. Wybór przykładów, [w:] Chrześcijański wschód a kultura polska, pod red. R. Łużnego, Lublin, s. $127-147$.

Klich E., 1927, Polska terminologia chrześcijańska, Poznań.

Rygorowicz-Kuźma A., 2011, Terminologia prawosławna w język polskim (na przykładzie nazw osób duchownych), „Acta Polono-Ruthenica”, XVI, Olsztyn, s. $403-413$.

Skowrońska-Płaczynta G., 1995, 1998, Православие. Лингводидактические материальи для студентов русской филологии, ч. 1-2, Kraków.

\section{ORTHODOX TERMINOLOGY IN THE RUSSIAN-POLISH SPECIALISTIC DICTIONARIES}

\author{
S U M M A R Y
}

This article focuses on Orthodox terminology found in modern Russian-Polish specialistic dictionaries: Chrześcijaństwo. Stownik rosyjsko-polski by R. Lewicki and Leksykon chrześcijaństwa rosyjsko-polski i polsko-rosyjski by A. Markunas, T. Uczitiel.

The author shows the extent given lexicon is reflected in dictionaries, explores the ways of its translation and presents strengths and weaknesses of elaboration of entry articles. The analysis of translated equivalents also permits the identification of the main tendencies in Orthodox terminology in the Polish language.

Anna Rygorowicz-Kuźma e-mail: anna.rygorowicz-kuzma@uwb.edu.pl 